\title{
Effect of Chitosan Nanoparticles and Pectin Content on Mechanical Properties and Water Vapor Permeability of Banana Puree Films
}

\author{
Milena R. Martelli, Taís T. Barros, Márcia R. de Moura, Luiz H. C. Mattoso, and Odilio B. G. Assis
}

\begin{abstract}
Puree prepared from over-ripe peeled bananas was used as raw material for films processing in a laboratory padder. Pectin and glycerol as plasticizer were added in small concentrations and chitosan nanoparticles $(88.79 \pm 0.42$ $\mathrm{nm}$ medium size) incorporated at $0.2 \%$ (dry weight basis) as reinforcement material. The mechanical properties, water vapor transmission, thermal stability, and scanning electron microscopy of fractured film surfaces were characterized. Both pectin and glycerol demonstrated an important role in promoting elongation and film handability as was expected. The incorporation of nanoparticles promoted noticeable improvement of the mechanical properties and acted in reducing the water vapor permeation rate, by $21 \%$ for films processed with pectin and up to $38 \%$ for films processed without pectin, when compared to the control (puree films with no pectin and nanoparticles additions). Microscopic observation revealed a denser matrix when nanoparticles are incorporated into the films.
\end{abstract}

Keywords: banana puree, chitosan nanoparticles, edible films, mechanical properties

Practical Application: The development of films from fruit purees head to a new strategy for plastic processing from natural resources. The over-ripe or even waste banana can be adequately prepared for batch films processed with reasonable mechanical and barrier properties, suitable for applications in the food segment. The addition of small fractions of chitosan nanoparticles, form nanocomposites enhancing mechanical and thermal stability broadening potential film applications.

\section{Introduction}

The development of polymeric materials, based on renewable resources has become increasingly important in recent years, due to the inevitable rising prices of petroleum-based materials and environmental concerns. Proteins (collagen, gluten, and zein) and polysaccharides (alginate, starch, chitosan, and cellulose) have historically been the most tested renewable materials for film processing. As of 1996, a fruit puree was suggested as an alternative source for producing flexible films (McHugh and others 1996). Apple, peach, apricot, and pear purees were tested as films precursors, resulting in materials with good oxygen barriers and acceptable mechanical properties (McHugh and others 1996). Banana (Sothornvit and Pitak 2007), tomato (Du and others 2008), mango (Azeredo and others 2009), and carrot (Wang and others 2011) also have potential to be transformed into purees suitable for edible films forming. Since the purees are mainly composed of cellulosic and pectic substances, they can be processed not only

MS 20120948 Submitted 7/12/2012, Accepted 10/16/2012. Authors Milena R. Martelli, Taís T. Barros, Márcia R. de Moura, Luiz H. C. Mattoso, and Odilio B. G. Assis are with Natl. Nanotechnology Laboratory for Agriculture, Embrapa Instrumentação, Rua XV de Novembro, 1452-13561-206 São Carlos, SP, Brazil. Author Márcia R. de Moura is with IFSC, Nanomedicine Laboratory, Univ. of São Paulo-USP, Av. Trabalhador São-carlense, 400-13560-970 São Carlos, SP, Brazil. Direct inquiries to author Odilio Benedito Garrido Assis (E-mail: odilio.assis@gmail.com). from fresh fruit, but also from industrial byproducts or even from waste. This is particularly important for seasonal fruits for which a large proportion is discarded (Gustavsson and Stage 2011).

Banana, for example, is a highly perishable and fragile fruit. From harvest to market, losses can reach up to $50 \%$ of the total volume produced (SEBRAE 2008). In unripe bananas, starch is the main component (around $220 \mathrm{mg}$ per gram of fruit; Shiga and others 2011). During ripening, the starch is converted into soluble sugars contributing to pulp softening. Pectin $(\mathrm{Pec})$ content in bananas is found in lower levels and, depending on the cultivar, its concentration decreases during ripening, from around 12 to $6.7 \mathrm{mg}$ per gram of fruit (Prabha and Bhagyalaksmi 1988). Banana puree is therefore of interest as raw material for plastic processing.

Generally films from fruit puree offer poor flexibility, requiring the addition of plasticizers to improve toughness and processability. Recently the incorporation of cellulose nanofibers (Azeredo and others 2009) and chitosan nanoparticles (ChNp; Lorevice and others 2012) have been evaluated as reinforcement materials within the puree film matrix.

The formation of nanocomposites, either by fiber or particle addition, proved very useful in enhancing both mechanical and barrier properties (Azeredo and others 2009). Additionally chitosan is known to possess good antifungal and antibacterial properties (Devlieghere and others 2004; Dutta and others 2009; Vasconez and others 2009), both desirable for food applications.

In this study, the key aim was to produce and characterize edible films based on over-ripe banana puree, with small additions of $\mathrm{Pec}$ 
and glycerol (Gly) as plasticizers. ChNp were also incorporated in the film formulation and the thermal, mechanical, water barrier, and antimicrobial properties were evaluated.

\section{Materials and Methods}

\section{Preparation of banana puree}

The banana puree was produced according to the procedure described by Tadini and Ditchfield (2005), with some modifications. A total $750 \mathrm{~g}$ of over-ripe peeled bananas, variety "nanica" (Musa cavendishii Lamb.), ripening stage 7 to 8 (yellow peel with a few brown spots; Emaga and others 2007), and $25 \pm 2{ }^{\circ}$ Brix, were mixed in $250 \mathrm{~g}$ of distilled water for $3 \mathrm{~min}$. The puree was acidified with a combined solution of citric and ascorbic acid, both at $0.2 \%(\mathrm{w} / \mathrm{w})$. The mixture was centrifuged for $5 \mathrm{~min}$ at $12000 \mathrm{rpm}$ and the supernatant discarded. The puree underwent heat treatment at $115^{\circ} \mathrm{C}$ for $60 \mathrm{~s}$ for enzyme inactivation and was then packaged in plastic bags, sealed and frozen at $-18^{\circ} \mathrm{C}$.

\section{ChNp}

ChNp were obtained by polymerizing methacrylic acid (MAA) in the presence of chitosan solution (medium molecular weight, product code 448877), both from Aldrich (St. Louis, MO, USA), according to the sequence described by Moura and others 2008. In an aqueous MAA solution ( $0.5 \% \mathrm{v} / \mathrm{v}), 0.2 \%$ (dry weight basis) of chitosan was dissolved under moderate magnetic stirring for 12 h. Then, $0.2 \mathrm{mmol}$ of potassium persulfate $\left(\mathrm{K}_{2} \mathrm{~S}_{2} \mathrm{O}_{8}\right)$ was added and the solution heated at $70{ }^{\circ} \mathrm{C}$ for $1 \mathrm{~h}$. The suspension was centrifuged for $30 \mathrm{~min}$ at $4000 \mathrm{rpm}$ and the supernatant discarded. The resultant $\mathrm{ChNp}$ were resuspended in $\mathrm{NaCl}(1.0 \mathrm{mmol} / \mathrm{L})$ solution in a concentration of $15 \%$ (wt.). The zeta potential and the particle size distribution were measured at room temperature using a Zeta Potential Analyser (Zetasizer ZS 3600, Malvern Instruments, Malvern, UK) at $\mathrm{pH}$ range of 3.5 to 8.5 . The $\mathrm{ChNp}$ obtained via MAA polymerization have been confirmed to be nontoxic according to analysis performed by Lima and others, 2010.

\section{Film processing}

The tested formulations were: banana puree at $4.5 \%$ and $6.0 \%$ (grams of dry weight per $100 \mathrm{~g}$ of total solution); Pec at $0.25 \%$, $0.5 \%$, and $0.75 \%$ (grams Pec per $100 \mathrm{~g}$ total solution), and Gly at $5 \%$ or $10 \%$ (grams Gly per $100 \mathrm{~g}$ dry weight puree). All mixtures were first homogenized for $24 \mathrm{~h}$ under moderate stirring. The film processing was carried out using a laboratory padder (Werner Mathis AG, Niederhasli, Switzerland) running in batch mode. On the surface of a polyester film $(14 \times 20 \mathrm{~cm}), 80 \mathrm{~g}$ of film solution were added as support, and films obtained after 2 cycles of $40 \mathrm{~min}$ at $50^{\circ} \mathrm{C}$.

The formulation $4.5 \%$ of banana puree plus $5 \%$ of Gly was selected to receive $0.2 \%$ of nanoparticles $(\mathrm{ChNp}$ ) resuspended solution, prior to film processing. All films were conditioned in desiccators containing saturated solutions of $\mathrm{NaBr}$ ( $58 \%$ relative humidity $[\mathrm{RH}]$ ) for $4 \mathrm{~d}$ before any characterization

\section{Mechanical properties}

Film thickness was measured using a digital micrometer (Mitutoyo Corp., Kawasaki-shi, Japan). Three values were taken at random locations along the length of each sample and the mean value used for calculation.

Uniaxial tensile tests were conducted until film fracture on a Texture Analyzer TA.XT Plus (Stable Micro System, Surrey, UK), with a $50 \mathrm{~N}$ load cell and tensile grips at initial separation of $80 \mathrm{~mm}$. The tests were run using rectangular samples of $100 \mathrm{~mm}$ $\times 16 \mathrm{~mm}$ and cross-head speed of $80 \mathrm{~mm} / \mathrm{min}$, in accordance to ASTM D882-97 (ASTM 1997). Stress-strain curves were obtained for each test, and the analyzed parameters were: the ultimate stress $\left(\sigma_{\max }, \mathrm{MPa}\right)$, the elongation at break $\left(\varepsilon_{\max }, \%\right)$ and the Young's modulus $(E)$ calculated as the slope of the linear portion of the stress-strain curve $(E=\sigma / \varepsilon, \mathrm{MPa})$.

\section{Thermal properties}

Thermal characterization was carried out using a Q100 Differential Scanning Calorimeter (TA Instruments, New Castle, DE, USA). Approximately $5 \mathrm{mg}$ of films was accurately weighed, sealed into aluminum pans and heated from -60 to $210^{\circ} \mathrm{C}$ at a rate of $10^{\circ} \mathrm{C} / \mathrm{min}$.

The thermal degradation was analyzed in a Thermogravimetric Analyzer TGA-Q500 (TA Instruments, New Castle, DE, USA). The experiments were recorded in the temperature range of 20 to $700{ }^{\circ} \mathrm{C}$ (heating rate of $10{ }^{\circ} \mathrm{C} / \mathrm{min}$ ). The nitrogen flow was maintained at $60 \mathrm{~mL} / \mathrm{min}$. The analysis was repeated twice for each sample.

\section{Water vapor permeability of films}

Water vapor permeability (WVP) was determined using an adaptation of the ASTM E96-92 (ASTM, 1992) gravimetric method. Circular samples without defects were cut from each film. Distilled water $(6 \mathrm{~mL})$ was dispensed into flat-bottom Plexiglas cups with wide rims. The samples were sealed to the cup base with a ring located around the cup circumference $(6 \mathrm{~cm})$, fitting an effective film area of $28.27 \mathrm{~cm}^{2}$. The cups were allocated inside desiccators containing silica gel and placed in temperaturecontrolled cabinets at $25{ }^{\circ} \mathrm{C}$. The desiccators' internal $\mathrm{RH}$ was monitored using a hygrometer (OBH Nordica, Taastrup, Denmark) and weights taken periodically (Gehaka AG 2000 analytical scale, São Paulo, SP, Brazil) after steady state was achieved.

The WVP was calculated by normalizing the data to the exposed area $(A)$, as described by Eq. 1:

$$
\mathrm{WVP}=\frac{w}{t} \cdot \frac{x}{A \cdot \Delta P}
$$

where $x$ is the films average thickness, $\Delta P$ the difference of partial vapor pressure of the atmosphere with silica gel and pure water $(100 \% \mathrm{RH})$, and the term $w / t$ calculated by the linear regression from the points of weight gain and time, in the constant rate period. All measurements were repeated 4 times.

\section{Microscopy features}

The microscopic characteristics of the films were observed in a JEOL JSM-6510 Scanning Electron Microscope (JEOL Ltd., Tokyo, Japan). Strips of film were fractured under nitrogen and mounted on aluminum stubs and coated with gold using a Balzers sputtering device (Balzers Union, Balzers, Liechtenstein). All of the samples were examined under an accelerating voltage of 1.5 $\mathrm{kV}$.

\section{Antimicrobial essay}

Antimicrobial activity of banana puree films were evaluated according to the zone of inhibition in disc diffusion method (Pelczar and others 1986). Petri dishes (9 $\mathrm{cm}$ of diameter) containing tryptic soy broth (TSB) and agar medium were prepared and Staphylococcus aureus (ATCC 25923) as gram-positive and, Escherichia coli (ATCC 
8739) as gram-negative bacteria models (provided by Fundação Tropical André Tosello, Campinas, SP, Brazil) inoculated after appropriate dilution.

Circular pieces of films with approximately $1.0 \mathrm{~cm}$ diameters were cut and placed on the surface of culture medium previously inoculated. The Petri dishes were stored at $30{ }^{\circ} \mathrm{C}$ for $48 \mathrm{~h}$ to allow bacteria growth. Inhibition zones were measured on bases in the average diameter of the clear zone directly on the dishes. Puree films with no CHNp was taken as a control sample and all experiments were repeated 3 times.

\section{Statistical analyses}

The experimental results of film thickness, tensile tests, WVP, and thermal measurements were compared by one-way analysis of variance (ANOVA) and Duncan mean comparison test (XLSTAT), considering the significance level for $P \leq 0.05$.

\section{Results and Discussion}

\section{Nanoparticles characterization}

The ChNp were characterized to confirm stability of the colloidal suspension. The size distribution fits a log-normal function (Figure 1A) with average particle size measured as 88.79 $\pm 0.42 \mathrm{~nm}$. Such dimensions are smaller than those obtained by Moura and others 2008, using the same process and concentration, describing particles with medium size as $111 \mathrm{~nm}$. The suspension of $\mathrm{ChNp}$ is $\mathrm{pH}$-sensitive (Figure $1 \mathrm{~B}$ ) with isoelectric point at $\mathrm{pH}$
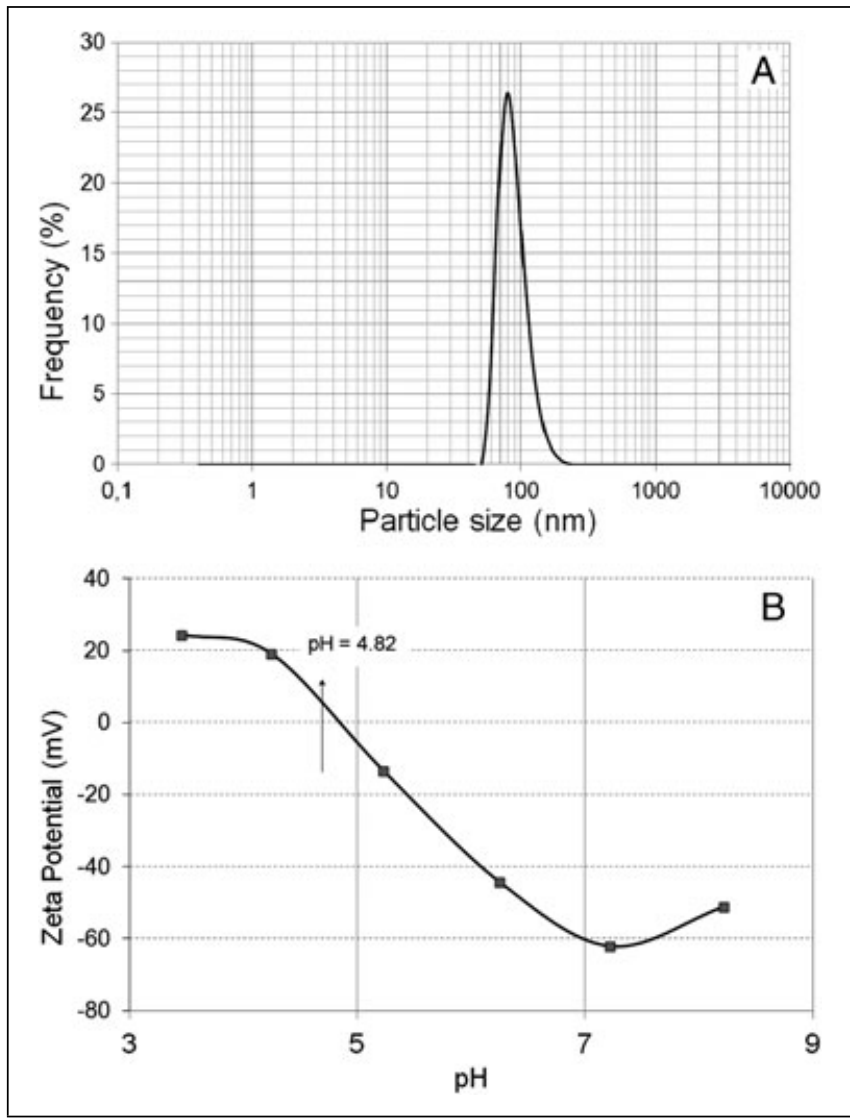

Figure 1-Characterization of chitosan nanoparticles solution $(0.2 \%)$ : (A) particle size distribution and (B) zeta potential in function of solution $\mathrm{pH}$. The arrow indicates the isoelelectric point according to Moura and others 2008.
Table 1- Effect of puree and plasticizer concentration on the mechanical properties of the tested films.

\begin{tabular}{lclllr}
\hline $\begin{array}{l}\text { Banana } \\
\text { puree }(\%)^{*}\end{array}$ & Gly $\mathbf{( \% ) ^ { \dagger }}$ & \multicolumn{1}{c}{$\begin{array}{c}\text { Thickness } \\
\mathbf{( m m})\end{array}$} & $\sigma_{\max }(\mathbf{M P a})$ & $\varepsilon_{\max }(\mathbf{\%})$ & $\boldsymbol{E} \mathbf{( M P a})$ \\
\hline 3 & 0 & $0.12 \pm 0.00^{\mathrm{a}}$ & $2.7 \pm 0.9^{\mathrm{a}}$ & $13 \pm 4^{\mathrm{a}}$ & $37 \pm 6^{\mathrm{a}}$ \\
& 5 & $0.14 \pm 0.01^{\mathrm{a}, \mathrm{b}}$ & $1.3 \pm 0.2^{\mathrm{b}, \mathrm{c}}$ & $27 \pm 2^{\mathrm{b}, \mathrm{c}}$ & $5 \pm 1^{\mathrm{b}}$ \\
& 10 & $0.14 \pm 0.02^{\mathrm{abc}}$ & $1.3 \pm 0.4^{\mathrm{b}}$ & $31 \pm 3^{\mathrm{b}}$ & $4 \pm 2^{\mathrm{b}}$ \\
4.5 & 0 & $0.15 \pm 0.00^{\mathrm{b}, \mathrm{c}, \mathrm{d}}$ & $3.9 \pm 0.6^{\mathrm{d}}$ & $10 \pm 2^{\mathrm{a}}$ & $70 \pm 5^{\mathrm{c}}$ \\
& 5 & $0.15 \pm 0.00^{\mathrm{b}, \mathrm{c}}$ & $3.2 \pm 0.5^{\mathrm{a}, \mathrm{d}}$ & $23 \pm 3^{\mathrm{c}, \mathrm{d}, \mathrm{e}}$ & $21 \pm 3^{\mathrm{d}}$ \\
6 & 10 & $0.17 \pm 0.00^{\mathrm{c}, \mathrm{d}}$ & $3.1 \pm 0.6^{\mathrm{a}, \mathrm{d}}$ & $19 \pm 2^{\mathrm{e}}$ & $27 \pm 4^{\mathrm{a}, \mathrm{d}}$ \\
& 0 & $0.17 \pm 0.00^{\mathrm{d}}$ & $6.9 \pm 0.6^{\mathrm{e}}$ & $13 \pm 1^{\mathrm{a}}$ & $120 \pm 17^{\mathrm{e}}$ \\
& 5 & $0.16 \pm 0.00^{\mathrm{b}, \mathrm{c}, \mathrm{d}}$ & $5.0 \pm 0.5^{\mathrm{f}}$ & $24 \pm 2^{\mathrm{c}, \mathrm{d}}$ & $34 \pm 2^{\mathrm{a}}$ \\
& 10 & $0.18 \pm 0.02^{\mathrm{d}}$ & $2.4 \pm 0.6^{\mathrm{a}, \mathrm{c}}$ & $19 \pm 4^{\mathrm{d}, \mathrm{e}}$ & $19 \pm 4^{\mathrm{d}}$ \\
\hline
\end{tabular}

Means with different superscript letters (a to f) are statistically different at $P<0.05$.

* (g of dry weight $/ 100 \mathrm{~g}$ of total solution) with $0.5 \%$ addition of pectin.

(g glycerol/100 g dried puree).

$=4.82$ as determined by Moura and others 2008. In order to retain a moderate stability of the colloidal suspension, film solutions were then prepared at $\mathrm{pH} 4.0$.

\section{Effect of puree and Gly concentrations on mechanical properties}

The resulting films processed with the Mathis padder have homogeneous thickness, good handability, and acceptable visual appearance. The concentration of puree, despite having an relatively low effect on film thickness, acted significantly on its mechanical properties. An increasing on the Young modulus $(E)$ and ultimate stress $\left(\sigma_{\max }\right)$ was observed as the puree concentration increases from $3 \%$ to $6 \%(\mathrm{w} / \mathrm{w})$ (Table 1$)$.

No significant statistical variation was observed in filme elongation. The mechanical properties of the film were modified, as expected by the addition of plasticizer. For all puree concentrations an increasing in around 2 to 2.5 times for $\varepsilon_{\max }$ was recorded for an addition of $5 \%$ or $10 \%$ Gly, confirming its plasticizing effect. Conversely $\sigma_{\max }$ and $E$ experienced a lowering of their comparative values, mainly $E$ which was significantly reduced bearing a decrease in the stiffness as the plasticizer content increases (Table 1).

The effect of polyols as plasticizer in the structure of natural polymers has been discussed by several authors (Sobral and others 2001; Scramin and others 2011). Plasticizers are small molecules with high degree of interaction between adjacent polymer chains. Such interactions generate "free volumes" between chains, weakening the intermolecular forces and consequently increasing the molecular mobility. Gly $\left(\mathrm{C}_{2} \mathrm{H}_{8} \mathrm{O}_{3}\right)$ in particular is a small molecule having 3 hydroxyl groups that are responsible for its ability to bind to the polymer backbone, distancing one from another. As more Gly is added to the formulation, more interactions are stablished along the chains groups until saturation. This implies an increase in the overall film plasticity and a reduction on the glass transition temperature.

The sugars present in the puree can also act as natural plasticizers. However, in the adopted process, the sugar content of banana puree was partially removed by centrifugation, before film processing.

\section{Effect of Pec additions on the mechanical properties}

In a cellulosic medium, Pec can form intermolecular junctions between its homogalacturonic regions and the cellulose chains and microfibrils (Zykwinska and others 2007). Small fractions of Pec can be used to enhance mechanical properties and to reduce the amount of puree used in the film's processing. Moreover, $\mathrm{Pec}$ also counterbalances certain negative effects, which may arise from the 
Table 2-Effect of pectin addition on the mechanical properties of the tested films.

\begin{tabular}{lccccc}
\hline $\begin{array}{l}\text { Banana } \\
\text { puree }(\%)^{*}\end{array}$ & $\mathbf{P e c}_{\dagger}$ & $\begin{array}{c}\text { Thickness } \\
\mathbf{( m m )}\end{array}$ & $\begin{array}{c}\sigma_{\max } \\
\mathbf{( M P a})\end{array}$ & $\varepsilon_{\max }(\%)$ & $\boldsymbol{E} \mathbf{( M P a )}$ \\
\hline 3 & 0 & $\mathrm{NF}_{\ddagger}$ & $\mathrm{NF}$ & $\mathrm{NF}$ & $\mathrm{NF}$ \\
& 0.5 & $0.12 \pm 0.00^{\mathrm{a}}$ & $2.7 \pm 0.8^{\mathrm{a}, \mathrm{b}}$ & $13 \pm 4^{\mathrm{a}}$ & $37 \pm 5^{\mathrm{a}}$ \\
& 0.75 & $0.13 \pm 0.00^{\mathrm{a}, \mathrm{b}}$ & $4.3 \pm 0.7^{\mathrm{b}}$ & $16 \pm 4^{\mathrm{a}, \mathrm{b}}$ & $53 \pm 3^{\mathrm{b}}$ \\
$4.5+5 \%$ Gly & 0 & $0.13 \pm 0.00^{\mathrm{a}, \mathrm{b}}$ & $1.1 \pm 0.2^{\mathrm{c}, \mathrm{e}}$ & $15 \pm 2^{\mathrm{a}, \mathrm{b}}$ & $11 \pm 2^{\mathrm{c}}$ \\
& 0.5 & $0.15 \pm 0.00^{\mathrm{b}}$ & $3.2 \pm 0.5^{\mathrm{a}}$ & $24 \pm 3^{\mathrm{c}}$ & $21 \pm 3^{\mathrm{d}}$ \\
$6+10 \%$ Gly & 0 & $0.20 \pm 0.00^{\mathrm{c}}$ & $0.7 \pm 0.2^{\mathrm{e}}$ & $14 \pm 2^{\mathrm{a}}$ & $9 \pm 2^{\mathrm{c}}$ \\
& 0.25 & $0.17 \pm 0.01^{\mathrm{d}}$ & $2.0 \pm 0.2^{\mathrm{c}, \mathrm{d}}$ & $24 \pm 3^{\mathrm{c}}$ & $13 \pm 2^{\mathrm{c}}$ \\
& 0.5 & $0.18 \pm 0.02^{\mathrm{d}}$ & $2.4 \pm 0.6^{\mathrm{a}, \mathrm{d}}$ & $19 \pm 4^{\mathrm{b}, \mathrm{c}}$ & $19 \pm 4^{\mathrm{d}}$ \\
\hline
\end{tabular}

Means with different superscript letters (a to e) are statistically different at $P<0.05$.

* (g of dry weight/100 $\mathrm{g}$ of total solution).

(g pectin/100 g film solution)

¥No film formed (inadequate sample for mechanical testing).

Table 3-Effect of $0.2 \%(w / w)$ chitosan nanoparticles addition on film's mechanical properties.*

\begin{tabular}{lllccl}
\hline $\begin{array}{l}\text { Pec } \\
\mathbf{( \% )}\end{array}$ & $\begin{array}{c}\text { ChNp } \\
\mathbf{( \% )}\end{array}$ & $\begin{array}{c}\text { Thickness } \\
\mathbf{( m m})\end{array}$ & $\begin{array}{c}\sigma_{\max } \\
\mathbf{( M P a )}\end{array}$ & $\varepsilon_{\max }(\mathbf{\%})$ & $\boldsymbol{E} \mathbf{( M P a )}$ \\
\hline 0 & 0 & $0.13 \pm 0.00^{\mathrm{a}}$ & $1.1 \pm 0.1^{\mathrm{a}}$ & $15 \pm 2^{\mathrm{a}, \mathrm{b}}$ & $11 \pm 1^{\mathrm{a}}$ \\
& 0.2 & $0.12 \pm 0.00^{\mathrm{c}}$ & $0.9 \pm 0.2^{\mathrm{a}}$ & $12 \pm 2^{\mathrm{a}}$ & $14 \pm 5^{\mathrm{a}}$ \\
0.5 & 0 & $0.15 \pm 0.00^{\mathrm{d}}$ & $3.2 \pm 0.5^{\mathrm{c}}$ & $23 \pm 3^{\mathrm{c}}$ & $21 \pm 3^{\mathrm{b}}$ \\
& 0.2 & $0.13 \pm 0.00^{\mathrm{a}}$ & $4.5 \pm 0.7^{\mathrm{d}}$ & $18 \pm 2^{\mathrm{a}}$ & $43 \pm 3^{\mathrm{c}}$ \\
\hline
\end{tabular}

Means with different superscript letters (a to c) are statistically different at $P<0.05$.

* (4.5\% puree with 5\% Gly).

$\dagger$ (grams of pectin/100 $\mathrm{g}$ of film solution).

presence of Gly. The effect of Pec on the films is better observed in the parameters $E$ and $\sigma_{\max }$ when compared to pure puree films (Table 2). For the higher puree concentration $(6 \%$, d.b.) and high Gly content $(10 \%)$, the beneficial effects of Pec addition are more evident. When $0.25 \%$ of Pec is added, the ultimate stress increases around 3 times $\left(\sigma_{\max }=2.0 \pm 0.2 \mathrm{MPa}\right)$ and the elongation more than $70 \%\left(\varepsilon_{\max }=24 \pm 3 \%\right)$. For films containing an inferior puree concentration (3\%), more Pec is necessary to enhance the mechanical properties. In such cases $0.75 \%$ Pec increased $\sigma_{\max }$, from $2.7 \pm 0.8$ to $4.3 \pm 0.7 \mathrm{MPa}$, and $E$ from $37 \pm 5$ to 53 $\pm 3 \mathrm{MPa}$, whereas no significant difference was observed for the ultimate strain. It should be noted that $3 \%$ of puree without Pec did not produce films with sufficient consistency for mechanical analysis (Table 2).

According to the literature, most of films produced from fruit puree employed high quantities of puree, pure or plasticized, and the reported mechanical properties were quite similar as those reported here for banana puree (Sothornvit and Rodsamran 2008).

By comparing all parameters, a reasonable assumption was made to select an intermediary formulation (4.5\% puree, 5\% Gly, and $0.5 \% \mathrm{Pec}$ ), to receive the $\mathrm{ChNp}$ and its mechanical and permeability properties tested.

\section{Effect of ChNp addition on mechanical properties}

Table 3 shows the effect of $0.2 \% \mathrm{ChNp}$ addition (w/w) on mechanical properties of films. The presence of nanoparticles reduced elongation at break in approximately 20\% either for films added Pec. For films without PEC, the difference was not significant. Such a decrease is expected and may be understood as a consequence of the interfacial affinity between $\mathrm{ChNp}$ and the puree matrix. Additionally $\mathrm{ChNp}$ can diffuse and become entangled with the polymer matrix, filling voids spaces and consequently reducing plasticity. In banana-based puree films, the addition of $0.2 \%(\mathrm{w} / \mathrm{w}) \mathrm{ChNp}$ increases $\sigma_{\max }$ in around $40 \%$ for film with $0.5 \% \mathrm{Pec}(4.5 \pm 0.7 \mathrm{MPa})$, but remains almost unchanged for formulations without Pec.

The influence of nanoparticles on polymer composites has been studied and modeled for different systems and the influence on mechanical behavior currently discussed in terms of their different chemical or physical characteristics (Odegard and others 2005; Chang and others 2010). Particle-matrix with chemical similarities perform strong interaction, and when dispersed, the particles act as pinning centers, reducing chain mobility and promoting an improvement on the tensile strength (Chang and others 2010).

\section{Effect of the addition of Pec and ChNp on thermal and barrier properties}

The DSC thermograms obtained from the analysis of films (4.5\% puree, $5 \%$ Gly) containing Pec and/or ChNp are presented in Figure 2. A visible glass transition $\left(T_{\mathrm{g}}\right)$ followed by endothermic peak could be observed in the traces of the first scan for all samples. The endothermic peak varied from 138 to $148{ }^{\circ} \mathrm{C}$, subject to the film formulation. A reduction in endothermic values was observed when $\mathrm{Pec}$ and/or $\mathrm{ChNp}$ were added. The main contribution for this shift can be attributed to the nanoparticles, since the endothermic peak for chitosan is reported as being between 80 and $100{ }^{\circ} \mathrm{C}$ (Moura and others 2008) and for pure Pec $154{ }^{\circ} \mathrm{C}$ (Iijima and others 2000). This is also an indication that nanoparticles are well mixed into the matrix. Physically the presence of a non-intense endothermic peak is attributed to the evaporation of water associated with the hydrophilic groups and reflects the strength of water-polymer interaction (El-Hefian and others 2010).

Concerning the $T_{\mathrm{g}}$ values (Figure $2 \mathrm{~B}$ ), there is a slight decrease in this temperature (about $4^{\circ} \mathrm{C}$ ) observed for the films with $\mathrm{ChNp}$ $\left(T_{\mathrm{g}}=-44.3 \pm 0.7^{\circ} \mathrm{C}\right)$, regardless of Pec addition.

It is worth stressing that the main component of the films prepared in this study is banana puree, which may mask any Pec and $\mathrm{ChNp}$ effects. Furthermore food glass transitions are strongly dependent on water activity $\left(a_{\mathrm{w}}\right)$ what could be influenced by the drying process used (Rahman 2009).

According to Hofsetz and others 2007, the $T_{\mathrm{g}}$ of ripe bananas can range from $-15^{\circ} \mathrm{C}$ (for $\left.a_{\mathrm{w}}=0.11\right)$ to $-115^{\circ} \mathrm{C}$ (for $\left.a_{\mathrm{w}}=0.90\right)$, and for dried banana puree the $T_{\mathrm{g}}$ measured was $-34{ }^{\circ} \mathrm{C}$, inferior to our results. The importance of $T_{\mathrm{g}}$ lies in the stability of the food under different conditions. Despite $T_{\mathrm{g}}$ can be affected by factors such as sugar and other puree components, a lower transition temperature may suggests more water inside the matrix and consequently a weakening in the main film constituents interaction. The addition of ChNp does not appear to affect the film's $T_{\mathrm{g}}$.

Figure 3 shows the results of TG scans of pure banana puree and puree films $(4.5 \%$, d.b.) containing Gly, Pec, and/or ChNp. From these observations it is possible that the thermal degradation of films based on banana puree occurs in 3 stages. The 1st stage $\left(<100{ }^{\circ} \mathrm{C}\right)$ corresponds to the mass loss due to water evaporation that is naturally retained in the matrix. The mass then remains constant until approximately $130{ }^{\circ} \mathrm{C}$. Above this temperature, that is, after complete dehydration, sugar (fructose, glucose, and sucrose), starch and proteins begin to degrade irreversibly. The 3rd stage between 230 and $400{ }^{\circ} \mathrm{C}$ may be attributed to thermal deterioration of organic compounds (lignin, hemicellulose, and cellulose).

The results also indicate that the Gly addition as plasticizer (in the fractions used in this study) did not appear to influence the thermal degradation profile of the films. Conversely the presence of $\mathrm{ChNp}$ introduces positive effects on the thermal characteristics by increasing film stability. From the 2nd stage onwards, it was 
observed that for films with nanoparticles, thermal decomposition is reduced in comparison to films without $\mathrm{ChNp}$. It is evident that film-processing temperatures should not exceed $130{ }^{\circ} \mathrm{C}$ to avoid structural degradation.

The evaluation of WVP provides additional information that is valuable when identifying potential applications for these films. As displayed in Figure 4, the water barrier measured for banana puree films (WVP $=3.03 \pm 0.15 \mathrm{~g} \mathrm{~mm} / \mathrm{m}^{2} \mathrm{~h} \mathrm{kPa}$ ) appears to be lower than the permeabilities reported by McHugh and others 1996, measured in similar plasticized films processed from others fruit purees, that is, $\mathrm{WVP}=4.2$ for peach; 4.3 for apricot; 5.8 for apple; and $7.8 \mathrm{~g} \mathrm{~mm} / \mathrm{m}^{2} \mathrm{~h} \mathrm{kPa}$ for pear films.

The films reported in this study present higher rates of water transference than those of other macromolecular films, such as hydroxyl-propyl-methyl cellulose with WVP $=0.8$ (Moura and others 2009) and most protein-based films, normally hydrophobic materials with WVP varying from 1 to $0.7 \mathrm{~g} \mathrm{~mm} / \mathrm{m}^{2} \mathrm{~h} \mathrm{kPa}$ (Hettiarachchy and Eswaranandam 2005).

When ChNp is added, the barrier effect increases and the permeability drops by $21 \%$ and $38 \%$ in films with and without Pec respectively. Proportional reduction in WVP was also observed when
$\mathrm{ChNp}$ was added as a reinforcement material in methylcellulose based films (Moura and others 2009) and in poly(caprolactone)

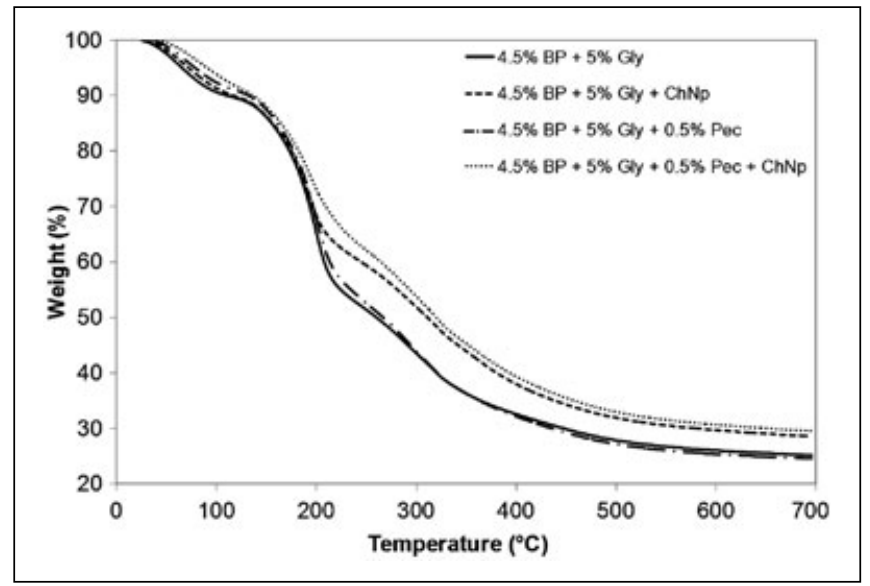

Figure 3-TG scans of banana base films with and without chitosan nanoparticles (heating rate: $10^{\circ} \mathrm{C} / \mathrm{min}$ ).

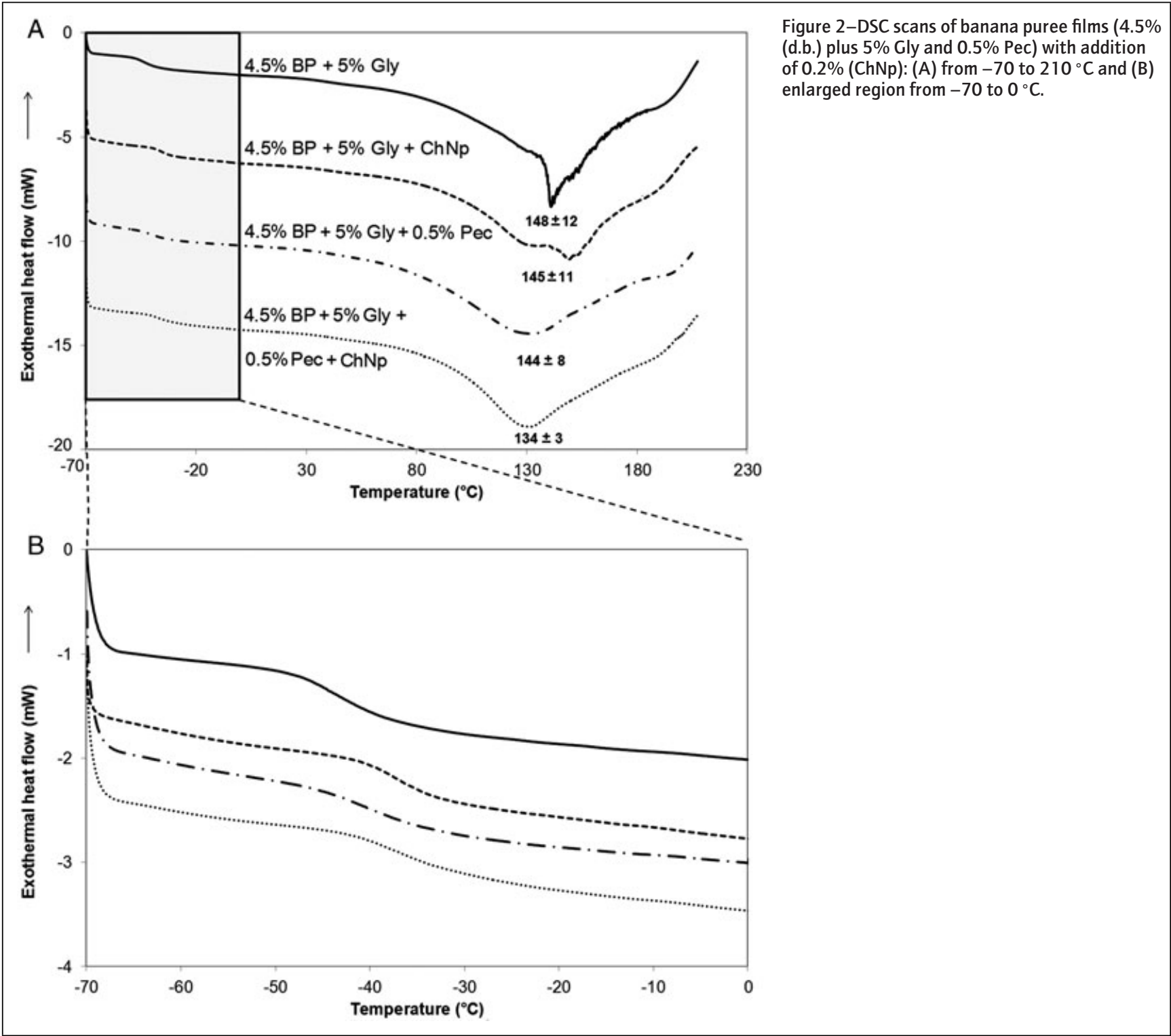


composites films (Sharmin and others 2012). This can be explained by the diffusion of $\mathrm{ChNp}$ during solvent evaporation and filling empty spaces in the film matrix.

\section{Film morphology and antimicrobial activity}

SEM images of film fractured surfaces are shown in Figure 5. The control sample ( $4.5 \%$ d.b. banana puree and $5 \%$ of Gly) resulted in a rough surface evidencing a plastic behavior. It is possible to observe internal pores, with variable dimensions randomly distributed inside the matrix. The ragged edge in the fracture region also evidenced plastic deformation in the direction to the applied force.

On the other hand, film with ChNp addition exhibited a smooth fracture surface revealing a dense internal structure and straight edge, characterizing a more brittle rupture in agreement with its mechanical parameters. By SEM observation, no agglomerates of nanoparticles were possible to be identified suggesting a good dispersion into the puree matrix. Both films have similar and smooth external surface.

The preliminary essays did not show any detectable antimicrobial activity, neither on $S$. aureus or E. coli, as evaluated by diskdiffusion method. Despite reports of good activity of ChNp (either as isolated particles [Qi and others 2004] or dispersed in a gel medium [Leonida and others 2011]), against both gram-positive and gram-negative bacteria, in our evaluation the incorporation of ChNp at $0.2 \%(\mathrm{w} / \mathrm{w})$ in films did not cause any perceptible inhibition on the bacterial growth when compared to the control sample (film without ChNp).

One possible explanation is that physical contact between bacterial cells and chitosan polymer chains should be effective to

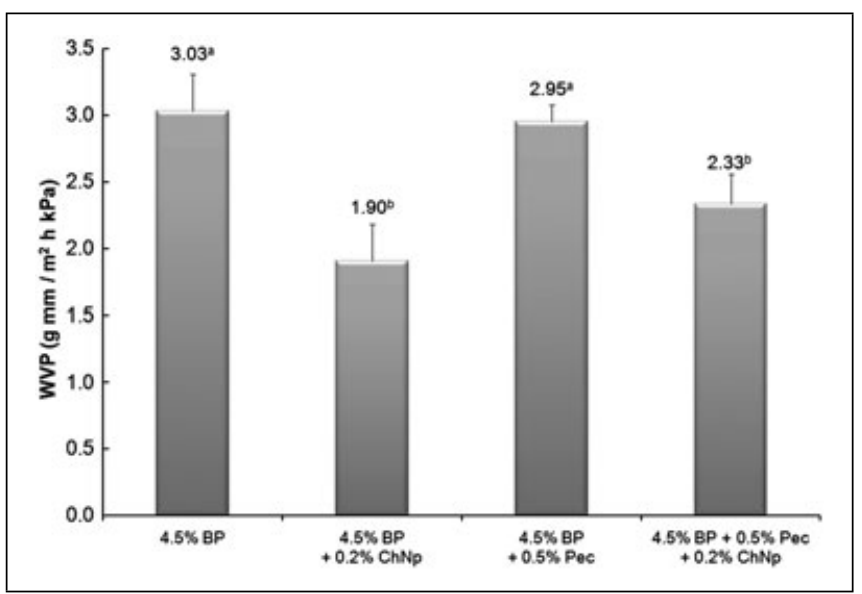

Figure 4-Water vapor permeability (WVP) of tested films with and without ChNp addition. All formulations have $5 \%$ Gly added. Different superscript letters ( $a$ and $b$ ) are statistically different at $P<0.05$.

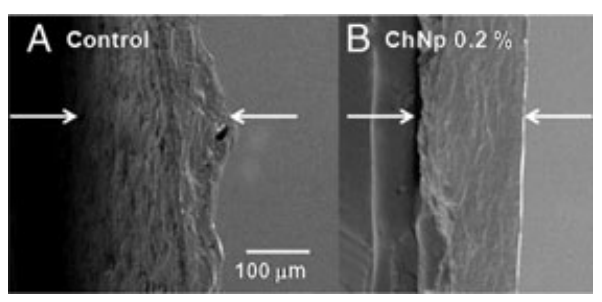

Figure 5-Scanning electron micrographs of film fractured surfaces. (A) Control sample ( $4.5 \%$ of banana puree and $5 \%$ Gly). (B) Same formulation with addition of $0.2 \mathrm{wt} . \%$ of CHNp. establish an ionic interaction between species thus effecting the antimicrobial activity (Goy and others 2009). The small amount of nanoparticles used in this study $(0.2 \%)$, along with the spatial dispersion inside the film matrix in where its main groups are bound to cellulose structure may reduce the probability of having a reasonable number of particles allocated on film surface with free active groups available for bacteria interaction.

Another reason is that banana puree, the major film constituent, contains natural compounds that could serve as nutrients for microorganisms, thus promoting bacterial growth. In short, the use of ChNp, as antimicrobial agents, in puree-based films should be better investigated with different nanoparticles concentrations.

\section{Conclusion}

Over-ripe bananas purees can be satisfactory employed as raw material for edible film processing. Additions of Pec (0.5\%) and Gly $(5 \%)$ as plasticizer (both in grams per $100 \mathrm{~g}$ of film solution) can promote a significant improvement in elongation, implying better plasticity and handablility. Small amounts of $\mathrm{ChNp}(0.2 \mathrm{wt} . \%)$ were found to be sufficient as a reinforcement material, enhancing the overall mechanical properties. Additionally the presence of nanoparticles in the film matrix reduces significantly the water vapor permeation. The combined use of plasticizer, Pec and nanoparticles can adjusted for broadening potential film applications. It is also noted that for the amount of $\mathrm{ChNp}$ used $(0.2 \%$ $\mathrm{w} / \mathrm{w})$, no antibacterial activity due to chitosan was observed in the banana puree processed films.

\section{Acknowledgment}

The author thanks CNPq (grant 153519/2010-0) and Rede AgroNano (Embrapa) for financial support.

\section{References}

ASTM. 1992. Standard test methods for water vapor transmission of materials. Method E96-92. Annual book of American Standard Testing Methods. Philadelphia, PA: ASTM.

ASTM. 1997. Standard test method for tensile properties of thin plastic sheeting. D882-97. Annual book of American standard testing methods. Philadelphia, PA: ASTM

Azeredo HMC, Mattoso LHC, Wood D, Williams TG, Avena-Bustillos RJ, McHugh TH. 2009. Nanocomposite Edible Films from Mango Puree Reinforced with Cellulose Nanofibers. J Food Sci 74(5):N31-5.

Chang PR, Jianb R, Yub J, Mab X. 2010. Fabrication and characterisation of chitosan nanoparticles/plasticised-starch composites. Food Chem 120(3):736-40.

Devlieghere F, Vermeulen A, Debevere J. 2004. Chitosan: antimicrobial activity, interactions with food components and applicability as a coating on fruit and vegetables. Food Microbiol 21(6):703-14

Du WX, Olsen CW, Avena-Bustillos RJ, McHugh TH, Levin CE, Friedman M. 2008. Antibacterial activity against E-coli O157: H7, physical properties, and storage stability of novel carvacrol-containing edible tomato films. J Food Sci 73(7):M378-83.

Dutta PK, Tripathi S, Mehrotra GK, Dutta J. 2009. Perspectives for chitosan based antimicrobial films in food applications. Food Chem 114(4):1173-82.

El-Hefian EA, Nasef MM, Yahaya AH, Khan RA. 2010. Preparation and characterization of chitosan/agar blends: rheological and thermal studies. J Chil Chem Soc 55(1):130-6.

Emaga TP, Andrianaivo RH, Wathelet B, Tchango JT, Paquot M. 2007. Effects of the stage of maturation and varieties on chemical composition of banana and plantain peels. Food Chem 103(2):590-600.

Goy RC, de Britto D, Assis OBG. 2009. A review of the antimicrobial activity of chitosan Polímeros: Ciênc Tecnol 19(3):241-7.

Gustavsson J, Stage J. 2011. Retail waste of horticultural products in Sweden. Resour Conserv Recy 55(5):554-6.

Hettiarachchy NS, Eswaranandam S. 2005. Edible Films and Coatings from Soybean and Other Protein Sources. In: Shahidi F, editor. Bailey's industrial oil and fat products: industrial and nonedible products from oils and fats. 6th ed. vol. 6. Hoboken, N. Jersey, USA: John Wiley \& Sons, Inc. p 371-90.

Hofsetz K, Lopes CC, Hubinger MD, Mayor L, Sereno AM. 2007. Changes in the physical properties of bananas on applying HTST pulse during air-drying. J Food Eng 83(4):531 -40 .

Iijima M, Nakamura K, Hatakeyama T, Hatakeyama H. 2000. Phase transition of pectin with sorbed water. Carbohyd Polym 41(1):101-6.

Leonida MD, Banjade S, Vo T, Anderle G, Haas GJ, Philips N. 2011. Nanocomposite materials with antimicrobial activity based on chitosan. Int J Nano Biomat 3(4):316-34

Lima R, Feitosa L, Pereira AES, Moura MR, Aouada FA, Mattoso LHC, Fraceto LF. 2010. Evaluation of the genotoxicity of chitosan nanoparticles for use in food packaging films. J Food Sci 75(6):N89-96.

Lorevice MV, de Moura MR, Aouada FA, Mattoso LHC. 2012. Development of novel guava puree films containing chitosan nanoparticles. J Nanosci Nanotechnol 12(3):2711-7. 
McHugh TH, Huxsoll CC, Krochta JM. 1996. Permeability properties of fruit puree edible films. J Food Sci 61(1):88-91.

Moura MR, Aouada FA, Avena-Bustillos RJ, McHugh TH, Krochta JM, Mattoso LHC. 2009. Improved barrier and mechanical properties of novel hydroxypropyl methylcellulose edible films with chitosan/tripolyphosphate nanoparticles. J Food Eng 92(4):448-53.

Moura MR, Aouada FA, Mattoso LHC. 2008. Preparation of chitosan nanoparticles using methacrylic acid. J Colloid Interf Sci 321(2):477-83.

Odegard GM, Clancy TC, Gates TS. 2005. Modeling of the mechanical properties of nanoparticle/polymer composites. Polymer 46(2): 553-62.

Pelczar M, Chan ECS, Krieg NR. 1986. Microbiology. New York, NY: McGraw-Hill. p 536.

Qi L, Xu Z, Jiang X, Hu C, Zou X. 2004. Preparation and antimicrobial activity of chitosan nanoparticles. Carbohyd Res 339(16):2693-700.

Prabha TN, Bhagyalakshmi N. 1998. Carbohydrate metabolism in ripening banana fruit. Phytochemistry 48(6):915-19.

Rahman MS. 2009. Food stability beyond water activity and glass transition: macro-micro region concept in the state diagram. Int J Food Prop 12(4):726-40.

Scramin JA, Britto D, Forato LA, Bernardes-Filho R, Colnago LA, Assis OBG. (2011). Characterisation of zein oleic acid films and applications in fruit coating. Int J Food Sci Tech 46(10):2145-52.

SEBRAE. 2008. Banana: Estudos de Mercado. In: Série Mercado:Report Sebrae/ESPM, Brasília, p 86.

Sharmin N, Khan RA, Salmieri S, Dussault D, Lacroix M. 2012. Fabrication and characterization of biodegradable composite films made of using poly(caprolactone) reinforced with chitosan. J Polym Environ 20(3):698-705.
Shiga TM, Soares CA, Nascimento JRO, Purgatto E, Lajolo FM, Cordenunsi BR. 2011 Ripening-associated changes in the amounts of starch and non-starch polysaccharides and their contributions to fruit softening in three banana cultivars. J Sci Food Agric 91(8): 1511-6.

Sobral PJA, Menegali FC, Hubinger MD, Roques MA. 2001. Mechanical, water vapor and thermal properties of gelatin based edible films. Food Hydrocolloid 15(4-6): 423-32.

Sothornvit R, Pitak N. 2007. Oxygen permeability and mechanical properties of banana films. Food Res Int 40(3):365-70.

Sothornvit R, Rodsamran P. 2008. Effect of a mango film on quality of whole and minimally processed mangoes. Postharvest Biol Technol 47(3):407-15.

Tadini CC, Ditchfield C. 2005. Produção de purê de banana de alta qualidade a partir de frutas rejeitadas para comercialização. In: Gerdal G, editor. Produção de Alimentos: busca de soluções para a fome. 20th ed. Porto Alegre: Gráfica e Editora Comunicação Impressa. p 47 -86 .

Vasconez MB, Flores SK, Campos CA, Alvarado J, Gerschenson LN. 2009. Antimicrobial activity and physical properties of chitosan-tapioca starch based edible films and coatings. Food Res Int 42(7):762-9.

Wang X, Sun X, Liu H, Li M, Ma Z. 2011. Barrier and mechanical properties of carrot puree films. Food Bioprod Process 89(2):149-1561.

Zykwinska A, Gaillard C, Buléon A, Pontoire B, Garnier C, Thibault J-F, Ralet M-C. 2007. Assessment of in vitro binding of isolated pectic domains to cellulose by adsorption isotherms, electron microscopy, and X-ray diffraction methods. Biomacromolecules 8(1):223-32. 